\title{
To taxonomy of the genus Cleigastra Macquart, 1835 (Diptera: Scatophagidae) with description of two new species
}

\author{
К таксономии двукрылых рода Cleigastra Macquart, 1835 \\ (Diptera: Scatophagidae) с описанием двух новых видов
}

\author{
A.L. Ozerov ${ }^{1}$, M.G. Krivosheina ${ }^{2}$

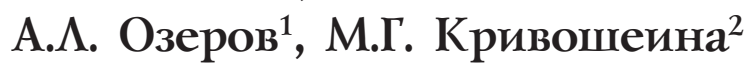

\footnotetext{
${ }^{1}$ Zoological Museum, Moscow Lomonosov State University, Bol’shaya Nikitskaya 2, Moscow 125009, Russia. E-mail: ozerov2455@rambler.ru 1 Зоологический музей, Московский государственный университет им. М.В. Ломоносова, Большая Никитская ул., 2, Москва 125009 , Россия.

${ }^{2}$ A.N. Severtzov Institute of Ecology and Evolution, Russian Academy of Sciences, 119071 Moscow, Russia. E-mail: dipteramarina@rambler.ru

${ }^{2}$ Институт проблем экологии и эволюции им. А.Н.Северцова РАН, Ленинский проспект, 33, Москва 119071, Россия.
}

KEYWORDS: Diptera, Scathophagidae, Cleigastra, new species, Russia.

КЛЮЧЕВЫЕ СЛОВА: Diptera, Scathophagidae, Cleigastra, новый вид, Россия.

ABSTRACT. It is offered to concern the genera Cleigastra Macquart, 1835, Gonarcticus Becker, 1894, Gonatherus Rondani, 1856, Nanna Strobl, 1894, Orthacheta Becker, 1894 and Spathephilus Becker, 1894 as one genus Cleigastra sensu lato with the three subgenera Cleigastra sensu stricto, Gonatherus and Orthacheta. Two species, new to science, are described: Cleigastra (Cleigastra) intermedia sp.n. from Novosibirsk Oblast and Khabarovsk Kray (Russia), and Cleigastra (Orthacheta) maritima sp.n. from Primorskiy Kray (Russia).

РЕЗЮМЕ. Предложено рассматривать роды Cleigastra Macquart, 1835, Gonarcticus Becker, 1894, Gonatherus Rondani, 1856, Nanna Strobl, 1894, Orthacheta Becker, 1894 и Spathephilus Becker, 1894 в одном роде Cleigastra sensu lato с тремя подродами Cleigastra sensu stricto, Gonatherus и Orthacheta. Описаны два новых для науки вида: Cleigastra (Cleigastra) intermedia sp.n. из Новосибирской области и Хабаровского края (Россия), и Cleigastra (Orthacheta) maritima sp.n. из Приморского края (Россия).

In our work with review of 7 genera of Scathophagidae of Russia we discussed if the genera Cleigastra Macquart, 1835, Gonarcticus Becker, 1894, Gonatherus Rondani, 1856, Nanna Strobl, 1894, Orthacheta Becker, 1894 and Spathephilus Becker, 1894 "might be better placed in one single genus Cleigastra sensu lato with two alternative compositions: with six subgenera (Cleigastra sensu stricto, Gonarcticus, Gonatherus, Nanna, Orthacheta and Spathephilus) or with only three subgenera (Cleigastra sensu stricto, Gonatherus and Orthacheta)" [Ozerov \& Krivosheina, 2015: 203].

It was demonstrated that such characters like the lack or presence of proepisternal hairs, presence or absence of setulae on vein $R_{1}$ or the number of setae on the scutellum are variable. They can therefore be used for separating species but not genera.

Basing on additional studied material (males of $C$. intermedia sp.n., see description below $)^{1}$ we make a conclusion to support the hypothesis on the necessity to unite abovementioned genera in one genus Cleigastra with three subgenera Cleigastra sensu stricto, Gonatherus and Orthacheta.

We consider Gonatherus and Orthacheta to be at subgeneric level because the females from these genera have ovipositor with moderate sternite 7, flattened laterally [Ozerov \& Krivosheina, 2015: Figs. 50-53, 171-174]. The species of Cleigastra sensu stricto posess simple sternite 7, segment 7 often forming sintergosternite [Ozerov \& Krivosheina, 2015: Figs. 14-16, 103, 179-181].

The nomenclatural summary is as follows.

Genus Cleigastra Macquart, 1835

Subgenus Cleigastra Macquart, 1835: 384. Gender: feminine. Type-species: Cordylura apicalis Meigen, 1826, by designation of Westwood, 1840 .

Cnemopogon Rondani, 1856: 100. Gender: masculine. Type-species: Cordylura apicalis Meigen, 1826, by original designation.

Gonarcticus Becker, 1894: 103. Gender: masculine. Typespecies: Scatomyza antennata Zetterstedt, 1838, by original designation - syn.n.

Nanna Strobl, 1894: 77 [as subgenus of Cordilura Fallén, 1810]. Gender: feminine. Type-species: Cordylura flavipes Fallén, 1819, by designation of Vockeroth, 1965) - syn.n.

Amaurosoma Becker, 1894: 109. Gender: neuter. Typespecies: Cordylura flavipes Fallén, 1819, by original designation.

${ }^{1} C$. intermedia has a pair of strong lateral scutellar setae and a pair of apical scutellar setulae (as in Cleigastra sensu stricto and in Nanna), proepisternum with hairs in central part (as in Nanna), and vein $\mathrm{R}_{1}$ setulose on apical third of dorsal surface (as in Cleigastra sensu stricto). 
Spathephilus Becker, 1894: 121. Gender: masculine. Typespecies: Cordylura breviventris Loew, 1873, by original designation - syn.n.

Pselaphephila Becker, 1894: 122. Gender: feminine. Type-species: Pselaphephila loewi Becker, 1894, by monotypy.

Monochaeta Becker, 1894: 87, 186. Gender: feminine. Junior secondary homonym, preoccupied byMonochaeta Brauer et Bergenstamm, 1890). Type-species: Cordylura breviventris Loew, 1873, by original designation.

Subgenus Orthacheta Becker, 1894: 101. Gender: feminine. Type-species: Cordylura pilosa Zetterstedt, 1838, by original designation - syn.n.

Orthochaeta: unjustified emend. [Aldrich, 1905: 567; Hendel, 1930: 8].

Orthacheta Rondani: error [wrong author diven by Vockeroth, 1995: 733].

Subgenus Gonatherus Rondani, 1856: 99. Gender: masculine. Type-species: Cordilura planiceps Fallén, 1826, by original designation - syn.n.

Additionally two new species are described in this work, based on material deposited in the Zoological Institute of Russian Academy of Sciences, St. Petersburg, Russia (ZISP), and Zoological Museum, Moscow State University, Russia (ZMUM).

The terminology used in the description of the new species follows McAlpine [1981], Cumming et al. [2009], and Stuckenberg [1999]. Dissected male genitalia were examined with a Nikon SMZ645 zoom stereomicroscope and then photographed using an eTREK DCM900 digital camera attached in place of an eyepiece of monocular microscope. Resulting batches of images were processed with CombineZP software [Hadley 2007], editing of stacked images was performed in Adobe Photoshop.

\section{Descriptions of new species}

\section{Cleigastra (Cleigastra) intermedia sp.n. Figs. 1-4.}

MATERIAL. Holotype $\sigma^{7}$, RUSSIA: Novosibirsk reg., Salair Range $\left(54.55^{\circ} \mathrm{N} 84.86^{\circ} \mathrm{E}\right), 11 . \mathrm{V} .2015$, O. Kosterin (ZMUM). Paratypes: $2 \sigma^{7} \sigma^{7}, 1$, data as for holotype (ZMUM); 1 , RUSSIA: Khabarovsk reg. Khicha river $\left(49.05^{\circ} \mathrm{N} 139.43^{\circ} \mathrm{E}\right), 690 \mathrm{~m}$, 10.VI.2014, N. Vikhrev (ZMUM); 1 9, RUSSIA: Khabarovsk reg. Manoma river $\left(49.44^{\circ} \mathrm{N} 137.41^{\circ} \mathrm{E}\right), 8 . \mathrm{VI} .2014, \mathrm{~N}$. Vikhrev (ZMUM). Both paratype females from Khabarovsk region were mentioned as Cleigastra apicalis (Meigen, 1826) by Ozerov \& Krivosheina [2015: 206].

DESCRIPTION. Male, female. Slender flies, about 3.7-6.2 mm long.

Head. Frontal vitta matt, black in upper part and yellow in lower third or half; fronto-orbital plate black, with greyish pollen. Face, parafacial and gena pale yellow. Postcranium black, greyish dusted, covered with whitish and black hairs and with row of black postocular setulae. Setae: 3 orbitals, 3 frontals, 1 ocellar, 1 inner vertical, 1 outer vertical (short), 1 postocellar; 1 pair of strong vibrissae and $1-2$ pairs of short subvibrissae present. Antenna black. Postpedicel with acutely angled upper apical corner, about 3 times as long as wide. Arista black, pubescent throughout its length. Palpus slender, yellow.

Thorax black, grey dusted. Acrostichals short in two or three rows, prescutellar pair not differentiated or only slightly longer than the other acrostichals, dorsocentrals $3+3$, intra-alars $0+2$, supra-alars $1+2$, postpronotals 2 , notopleurals 2 , postalars 2 . Proepisternum with hairs in central part (3-4 in female and only 1 in male), with 2 setae near lower margin. Proepimeron with 1 seta. Anepisternum covered with hairs in posterior part and with 4-5 black setae along posterior margin. Katepisternum covered with black setae in ventral corner and 3 strong katepisternal setae. Anepimeron bare. Scutellum black, with a pair of strong lateral scutellar setae and a pair of apical scutellar setulae.

Legs yellow, only fore femur posterodorsally, femora apex of mid and hind legs, coxae and tarsi of all legs darkened (Fig. 1). Fore femur with rows of posterodorsal (posterior) and anteroventral setae, with 3 anterodorsal and 4-5 anteroventral (in basal half) setae. Fore tibia with 1 posterodorsal, 2 dorsal (anterodorsal) and 1 posterior setae at middle, and ring of apicals. Mid femur with rows of anterior, and posteroventral setae, with 1 anteroventral seta in apical third, with 1 preapical posterior, and 1 preapical posterodorsal setae. Mid tibia with 2 posterodorsal, 2 anterodorsal, 1 posterior, 1 anteroventral setae, and ring of apicals. Hind femur with rows of anterodorsal, anteroventral and posteroventral setae, with 2 preapical anterior and 1 preapical posterodorsal seta. Hind tibia with 3 anterodorsal, 2 posterodorsal, 1 anteroventral, and ring of apicals, apical posteroventral setae present.

Wing clear or tinged with brownish; veins blackish; vein $R_{1}$ setulose on apical third of dorsal surface. Calypters, margins of calypters, and halteres yellowish.

Abdomen cylindrical, black, greyish dusted, covered with hairs. Tergites 2-6 each with row of marginal setae. Male sternite 4 simple, about 2 times as long as wide (Fig. 2). Male sternite 5 with triangular-shaped lobes (Fig. 2). Surstyli simple, cerci with long seta in middle (Figs 3, 4). Ovipositor moderately long, cylindrical; sclerites of ovipositor shining. Female tergite 7 desclerotized in middle, in some species forming syntergosternite; sternite 8 as two small round sclerites.

COMPARISON. The next combination of characters: 1) proepisternum with hairs in central part, 2) vein $R_{1}$ setulose on apical third of dorsal surface, 3) scutellum with a pair of strong lateral scutellar setae and a pair of apical setulae differentiate the new species from all other species of Cleigastra sensu lato.

\section{Cleigastra (Orthacheta) maritima sp.n.} Figs. 5, 7, 8-10.

MATERIAL. Holotype $\sigma^{7}$, RUSSIA: Primorskiy Kray, Gribnoe $\left(44.2574^{\circ} \mathrm{N} 132.6817^{\circ} \mathrm{E}\right), 10 \mathrm{~km}$ SE of Chernigovka, 19.V.1979, A. Zinoviev (ZISP). Paratype + , RUSSIA: Primorskiy Kray, Lazovskiy Reserve, Korpad' Cordon $\left(43.2529^{\circ} \mathrm{N} 134.1265^{\circ} \mathrm{E}\right), 19$ 20.V.2007, V. Sidorenko (ZMUM)

DESCRIPTION. Male, female. Slender fly, about $4.5 \mathrm{~mm}$ long. 


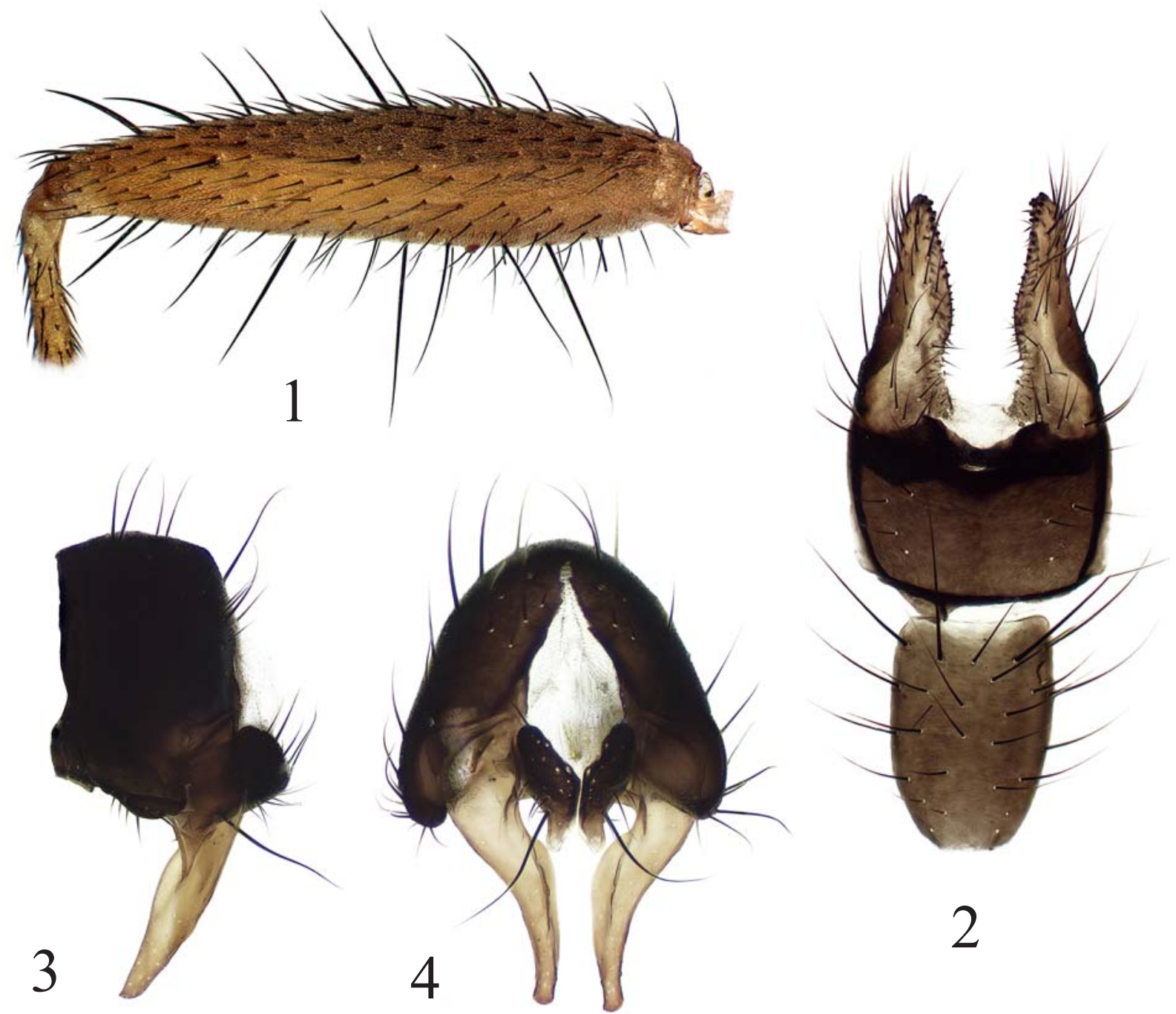

Figs 1-4. Cleigastra intermedia sp.n., holotype $\sigma^{7}: 1$ - fore femur, anterior view; 2 - sternites 4 (lower) and 5 (upper); 3 epandrium, cerci and surstyli, lateral view; 4 - same, dorsal view.

Рис. 1-4. Cleigastra intermedia sp.n., голотип О’: 1 — голень передней ноги, спереди; 2 - стерниты 4 (нижний) и 5 (верхний); 3 - эпандрий, церки и сурстили, сбоку; 4 - то же, сверху.

Head (Fig. 5). Frontal vitta matt, black in upper part and yellow in lower third; fronto-orbital plate black, with greyish pollen. Face, parafacial and gena pale yellow. Postcranium black, grey dusted, covered with yellow and black hairs and with row of black postocular setulae. Setae: 3 orbitals, 2 in female and $4-5$ in male frontals, 1 ocellar, 1 inner vertical, 1 outer vertical, 1 postocellar; 1 pair of strong vibrissae and 1-2 pairs of short subvibrissae present. Antenna black. Postpedicel with acutely angled upper apical corner, about 2 times as long as wide. Arista black, pubescent throughout its length (Fig. 5). Palpus slender, yellow.

Thorax black, grey dusted. Acrostichals short in two rows, prescutellar pair slightly longer than the other acrostichals, dorsocentrals (3-4)+3, intra-alars $(0-1)+2$ (very short in female), supra-alars $1+2$, postpronotals 1 in female and 2 in male, notopleurals 2, postalars 2. Proepisternum with hairs in central part, with 1 seta near lower margin. Proepimeron with 1 seta. Anepisternum covered with hairs in posterior part and with 2-4 black setae along posterior margin. Katepisternum covered with black in female and pale in male setae in ventral corner and 3 strong katepisternal setae. Anepimeron bare. Scutellum black, with a pair of strong basal scutellar and a pair of strong apical scutellar setae.

Legs yellow, only fore femur posterodorsally and tarsi of mid and hind legs darkened (Fig. 7). Fore femur with rows of anterodorsal (anterior), posterodorsal, posterior and ventral setae, in male additionally with long pale setae on posterior surface. Fore tibia with 1 posterodorsal, 2 dorsal (anterodorsal) and 1 posterior setae at middle, and with apicals: dorsal, ventral and posterior. Mid femur with rows of anterior, anteroventral and ventral (posteroventral) setae, 1 preapical posterior, and 1 preapical posterodorsal setae. Mid tibia with 2 


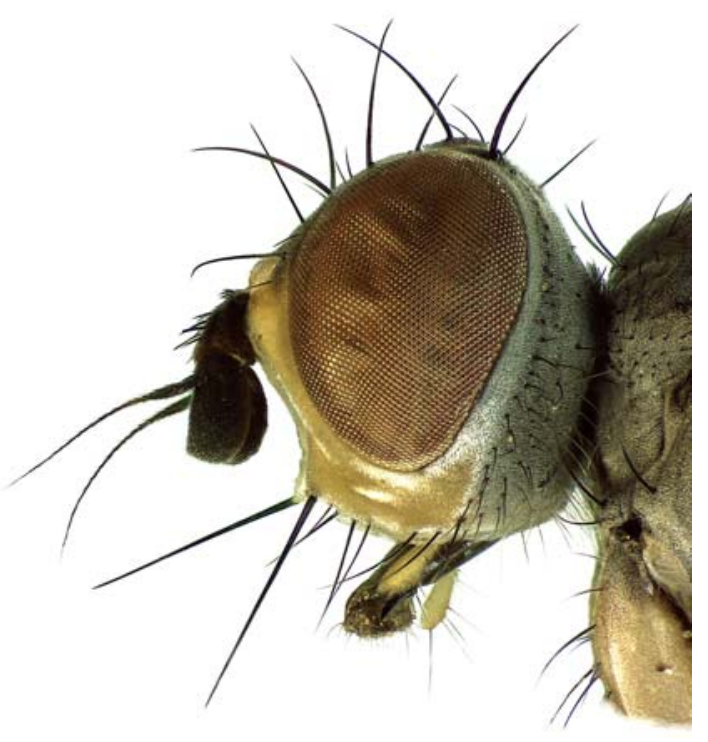

5

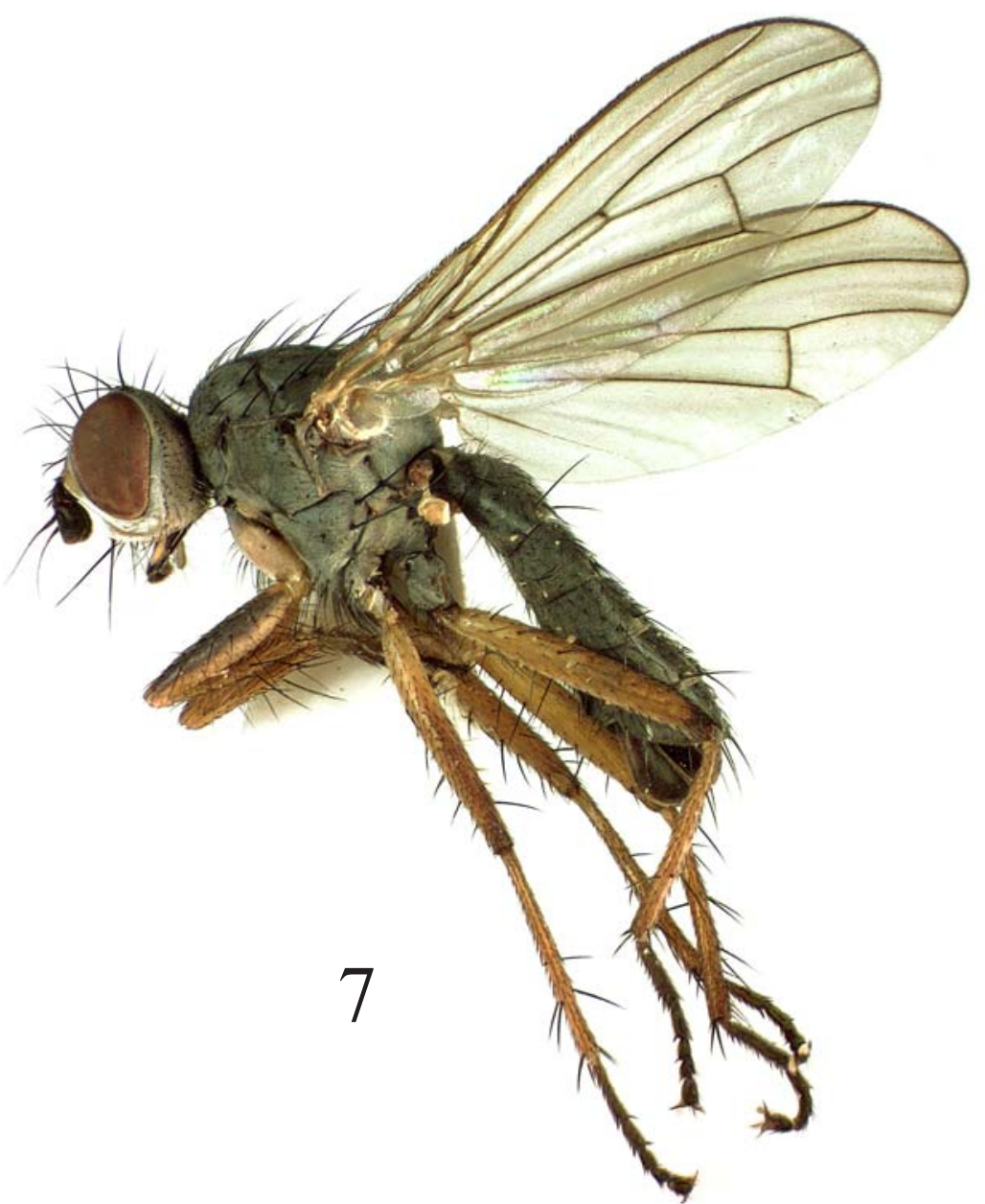

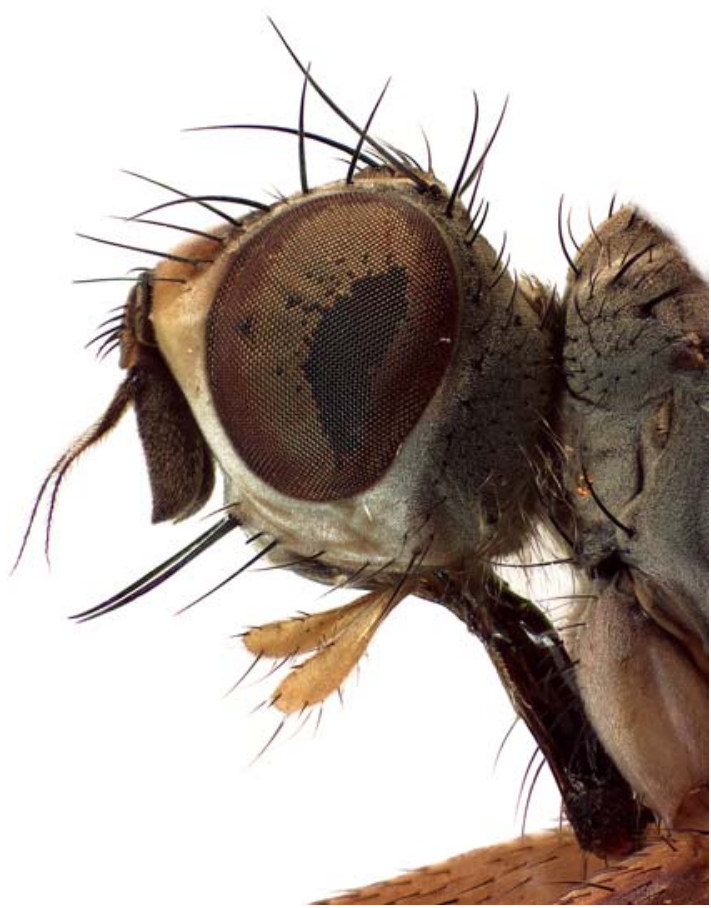

6

Figs 5-7. Cleigastra maritima sp.n. $(5,7)$ and Cleigastra strigipes (Johnson) (6), 우: 5, 6 - head, lateral view; 3 - habitus. Рис. 5-7. Cleigastra maritima sp.n. (5, 7) и Cleigastra strigipes (Johnson) (6), оㅇ: 5, 6 - голова, сбоку; 3 - общий вид. 

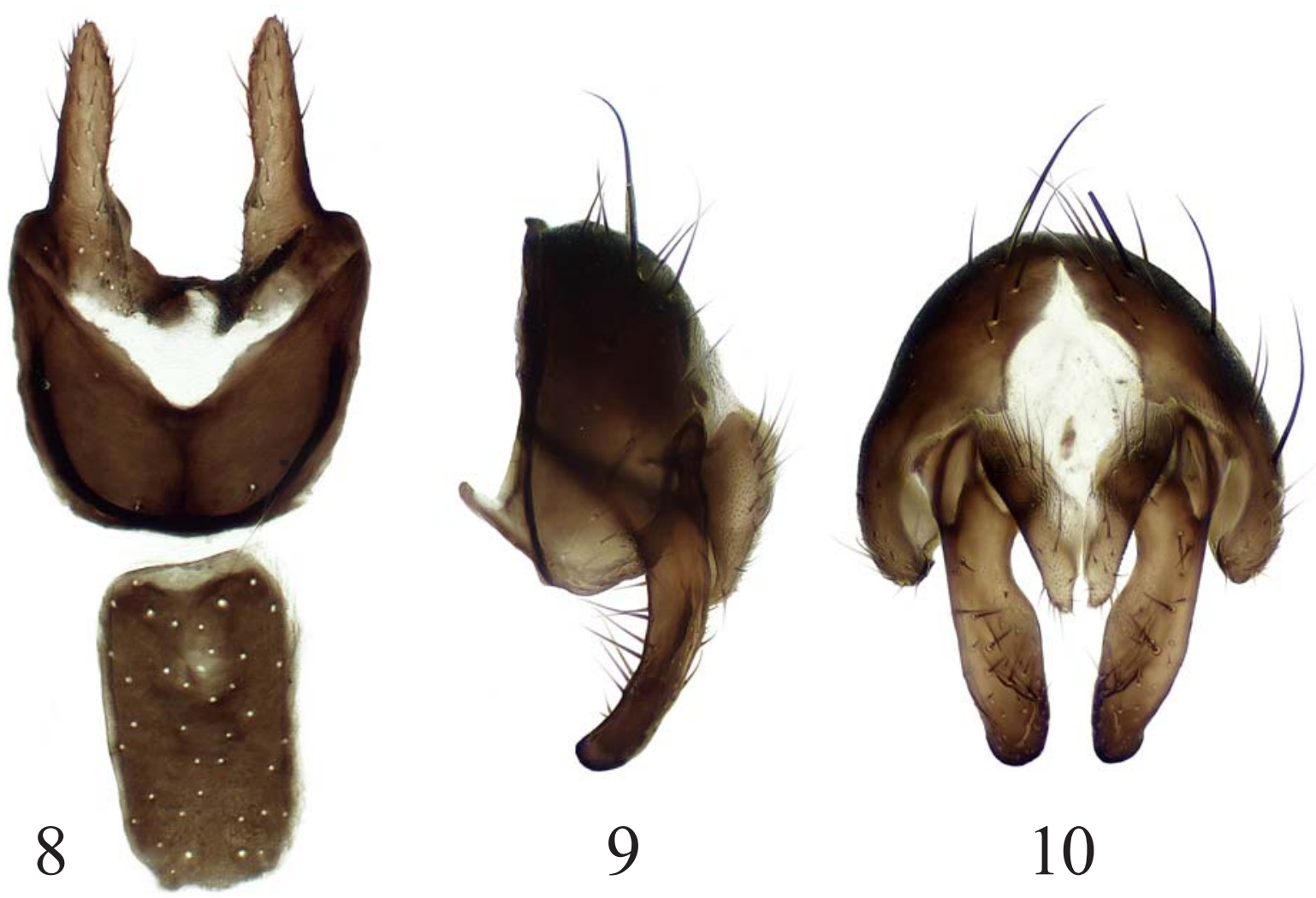

Figs 8-10. Cleigastra maritima sp.n., holotype $0^{7}: 8$ - sternites 4 (lower) and 5 (upper); 9 - epandrium, cerci and surstyli, lateral view; 10 - same, dorsal view.

Рис. 8-10. Cleigastra maritima sp.n., голотип О7: 8 - стерниты 4 (нижний) и 5 (верхний); 9 - эпандрий, церки и сурстили, сбоку; 10 - то же, сверху.

posterodorsal, 2 anterodorsal, 1 posterior, 1 anterior (anteroventral) setae, and ring of apicals. Hind femur with rows of anterodorsal and anteroventral setae and with 1 preapical posterior (posterodorsal) seta, and row of posteroventral setae, two of these in basal half very long. Hind tibia with 3 anterodorsal, 3 posterodorsal, 1 anteroventral, 1 preapical dorsal setae, and ring of apicals, apical posteroventral setae present.

Wing tinged with brownish, veins blackish; vein $\mathrm{R}_{1}$ setulose on apical third of dorsal surface. Calypters, margins of calypters, and halteres whitish.

Abdomen cylindrical, black, greyish dusted, covered with hairs. Tergites 2-6 each with row of marginal setae. Sternites 4 and 5 as in Fig. 8. Surstyli simple, long (Figs 9, 10).

COMPARISON. The new species is close to northamerican Cleigastra strigipes (Johnson, 1927) ${ }^{2}$, differing from it by short postpedicel, about 2 times as long as wide (Fig. 5), hind tibia with apical posteroventral setae, intra-alar setae very short (as setulae), two frontal setae present. C. strigipes has long postpedicel, about 3.5 times as long as wide (Fig. 6), hind tibia

2 The differences are based on the study of male (Canada: Alberta, Onefour $\left(49.1^{\circ} \mathrm{N} 110.4^{\circ} \mathrm{W}\right), 6$. VI.1955, J.R. Vockeroth) and female (Canada: Alberta, Drumheller $\left(51.4628^{\circ} \mathrm{N} 112.7053^{\circ} \mathrm{W}\right)$ 18.VI.1957, Brooks, MacNay) of Cleigastra strigipes. without apical posteroventral setae, intra-alar setae strong, four frontal setae present.

ACKNOWLEDGEMENTS. We are very grateful to Dr. O. Kosterin (Novosibirsk) for material of $C$. intermedia and Dr. James O'Hara (Ottawa) for the loan of specimens of $C$. strigipes for this study. We wish to thank Dr. Olga Ovchinnikova and Mrs. Galina Suleymanova for the help during our work in ZISP with the scathophagid collection.

Morphological studies and illustrations for this work were made on equipment purchased due to the support of RSF, research project No.14-50-00029.

\section{References}

Aldrich J. M. 1905. A catalogue of North American Diptera (or two-winged flies) // Smithsonian Institution, Smithsonian Miscellaneous Collections. Vol.46. No.1444. P.1-680.

Becker T. 1894. Dipterologische Studien. I. Scatomyzidae // Berliner Entomologische Zeitschrift. Bd.39. H.1. S.77-196.

Cumming J.M., Wood D.M. 2009. Adult morphology and terminology // Brown B.V., Borkent A., Cumming J.M., Wood D.M., Woodley N.E., Zumbado M. (eds.). Manual of Central American Diptera. Vol.1. Ottawa: National Research Council Press. P.9-50.

Hadley A. 2007. CombineZM. Open source image processing software package for creating extended depth of field images. Available from: http://www.hadleyweb.pwp.blueyonder.co.uk/ (accessed 17 January 2011) 
Hendel F. 1930. Entomologische Ergebnisse der schwedischen Kamtchatka-Expedition 1920-1922. 28. Diptera Brachycera 2. Fam. Cordyluridae und Dryomyzidae // Arkiv för Zoologi. Bd.21A. No.18. S.1-12.

Macquart J. 1835. Histoire naturelle des Insectes. Diptères. Vol.2. Paris: Roret. 710 pp.

McAlpine, J. F. 1981. Morphology and terminology-adults. Pp. 963. In: McAlpine J.F., Peterson B.V., Shewell G.E, Teskey H.J., Vokeroth J.R., Wood D.M., Coordinators. Manual of Nearctic Diptera. Volume 2. Research Branch. Agriculture Canada. Monograph 27, Ottawa. Vi+674 pp.

Ozerov A.L., Krivosheina M.G. 2015. A review of the genera Cleigastra Macquart, Gonarcticus Becker, Gonatherus Rondani, Hexamitocera Becker, Nanna Strobl, Orthacheta Becker and Spathephilus Becker (Diptera, Scathophagidae) of Russia // Zootaxa. Vol.4012. No.2. P.201-258.

Rondani C. 1856. Dipterologiae Italicae Prodromus. Vol. I. Genera Italica ordinis dipterorum ordinatim disposita et distincta et in familias et stirpes aggregata. Parmae. $228 \mathrm{pp}$.

Strobl G. 1894. Die Dipteren von Steiermark. II. Theil. // Mitteilungen des Naturwissenschaftlichen Vereines für Steiermark. Bd.30. S.1-152.

Stuckenberg B.R. 1999. Antennal evolution in the Brachycera (Diptera), with a reassessment of terminology relating to the flagellum // Studia Dipterologica. Vol.6. S.33-48.

Vockeroth J.R. 1995. Validation of nomina nuda of Nearctic Tethinidae, Scathophagidae, and Muscidae proposed in Manual of Nearctic Diptera // Proceedings of the Entomological Society of Washington. Vol.93. No.3. P.732-734. 